\title{
43. 中耳性耳漏の検出菌と薬剤感性
}

\author{
○小倉脩二・木 村繁・古屋正徳 \\ 小林康夫・細川彰・益子三郎
}

抗生剂の発達によつて, 細菌感染症の検出菌ならび に臨床像が著しく変化したことはいうまでもない。

検出菌に関していえば，緑膿菌をはじめとするグラ 么陰性桿菌の増加，而性菌の出現が指摘されている。 われわれは最近 5 年間における中耳性耳漏よりの検 出菌の動態について検討を加えた。期間は1963年 1 月 より1967年12月の 5 年間における1479株について検討 した。検出菌株数のすう勢は (第 1 表) に示すでとく で，第 1 位黄色ブドウ球菌462株（31\%)，第 2 位緑膿 菌301株 $(20.2 \%)$ であつた。

以下表皮ブドウ球菌261株 (17.6\%)，ジフテロイド 126 株 (8.5\%), プロテウス 72 株 $(4.9 \%)$, 真菌50株

(3.4\%)，肺炎双球菌42株 $(2.8 \%)$ ，クレブシェラ 32 株 $(2.2 \%)$ ，プロヴイデンシア 26 株 $(1.8 \%)$, 緑連菌 23 株 $(1.6 \%)$ の順であつた。

検出菌の年次別推移は（第1 表）に示すでとくであ ろが，黄色ブドウ球菌と緑澧菌に関して年次別推移を 百分比にて比較すると，(第 2 表)に示すでとくである. 年間平均 92 株で年次的に変動はみられない，一方緑澧 菌は年間平均60株が検出され，1965年後やや検出率が 低下している。

$\mathrm{Gr}(+)$ 球菌と $\mathrm{Gr}(-)$ 桿菌に大別すると, $\mathrm{Gr}(+)$ 球菌は 948 株で $64 \%, G r(-)$ 桿菌は 471 株で $31 \%$ であ つた. Gr (十) 球菌中に黄色ブドウ球菌の占める比率 は $48 \%$ で (第 3 表) に示すでとくであつた。一方緑膿 菌は $\mathrm{Gr}(-)$ 桿菌中 $64 \%$ を占め同様（第 3 表）に示す ごとくであつた。

急性中耳炎の最近数年間の顺出菌は（第 4 表）に示 すでとくで，黄色ブドウ球菌が45株ですつとも多い. 緑滕菌も10株検出されている。レンサ球菌の検出が比
較的少ない。

検出菌の薬剤感受性はデイスクによつて到定した。 黄色ブドウ球菌と緑澧菌の 2 種について，（卅）感受 性株を年次別に比較した (第 5 表)，薬剤感受性の順 位は 5 年間平均では, $\mathrm{CP}>\mathrm{TC}>\mathrm{EM}>\mathrm{SM}>\mathrm{PC}$ $>$ Sulfa 姷の順であつた。感受性の年次別推移は SM, CP, TC, EM においてほぼ変動はなかつた。 $\mathrm{PC}$, Sulfa 剤は上記薬剂に比し感受性低く, PC $の$ 感受性の低下傾向, Sulfa 剂の感受性の上向き傾向が みられた。緑滕菌においてはコリスチン（CL）が仕 倒的仼高い感受性を示した, 順位は $\mathrm{CL}>\mathrm{TC}>\mathrm{SM}$ $>$ Sulfa 剤>CP であつた。

\section{結 論}

(1) 黄色ブドウ球菌の検出は毎年第 1 位を占め，約 $30 \%$ の検出率を示した．緑膿菌がこれにつぎ約 $20 \%$ の 検出率を示した。

(2) 年次的に黄色ブドウ球菌検出率に変動はみられ なかつた。緑膿菌においては減少の㑯向がみられた。 その他真菌の検出数がやや增加している.

(3) 検出 $\mathrm{Gr}(+)$ 球菌中黄色ブドウ球菌は約 $50 \%$ \% 占め, $\mathrm{Gr}(-)$ 桿菌中緑澧菌は $64 \%$ を占めた。

(4) 急性中耳炎において検出第 1 位は黄色ブドウ球 菌で, 緑膿菌は10株検出された。レンサ球菌の検出は 少なかつた。

(5) 薬剤感受性

黄色ブドウ球菌 : $\mathrm{CP}>\mathrm{TC}>\mathrm{EM}>\mathrm{SM}>\mathrm{PC}>$ Sulfa剂. PC, Sulfa 剂の感受性は低い.

緑膿菌: $\mathrm{CL}>\mathrm{TC}>\mathrm{SM}>\mathrm{Sulfa}$ 剂 $>\mathrm{CP} . \mathrm{CL}$ の感受性はきわめて高かつた。

(6) 耐性菌の増加はみられなかつた。 
第 1 表 1963 1967年間の中耳性耳漏検出菌 （中央検查室）

\begin{tabular}{r|l|r|r|r|r|r|r|r}
\hline & 菌 & 1963年 & $1964 "$ & $1965 "$ & $1966 "$ & $1967 "$ & 計 & $\%$ \\
\hline \hline 1 & Staph. aureus & 76 & 87 & 87 & 121 & 91 & 462 & 31.0 \\
2 & Ps. aeruqinosa & 67 & 68 & 51 & 62 & 53 & 301 & 20.2 \\
3 & Staph. epidermidis & 46 & 40 & 60 & 76 & 39 & 261 & 17.6 \\
4 & Diphtheroid & 16 & 22 & 22 & 35 & 31 & 126 & 8.5 \\
5 & Proteus & 20 & 17 & 15 & 14 & 6 & 72 & 4.9 \\
6 & Fungus & 4 & 4 & 10 & 15 & 17 & 50 & 3.4 \\
7 & Dipl. pneumoniae & 2 & 4 & 6 & 19 & 11 & 42 & 2.8 \\
8 & Kleb. pneumoniae & 6 & 4 & 9 & 6 & 7 & 32 & 2.2 \\
9 & Providencia & 4 & 5 & 5 & 5 & 7 & 26 & 1.8 \\
10 & Strept. viridans & 6 & 4 & 2 & 8 & 3 & 23 & 1.6 \\
11 & etc & 18 & 12 & 21 & 16 & 17 & 84 & 6.0 \\
\hline & \multicolumn{1}{|c|}{ 計 } & 265 & 267 & 288 & 377 & 282 & 1479 & 100.0 \\
\hline
\end{tabular}

第 2 表 黄色ブドウ球菌，緑澧菌年次別推移

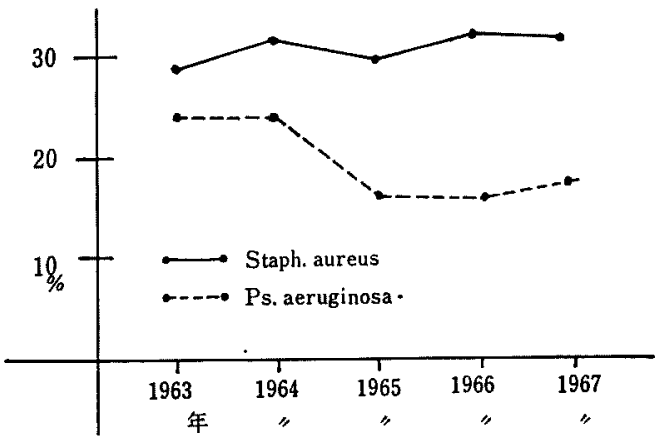

第 3 表 $\mathrm{Gr}(+)$ 球菌, $\mathrm{Gr}(-)$ 桿菌検出比率

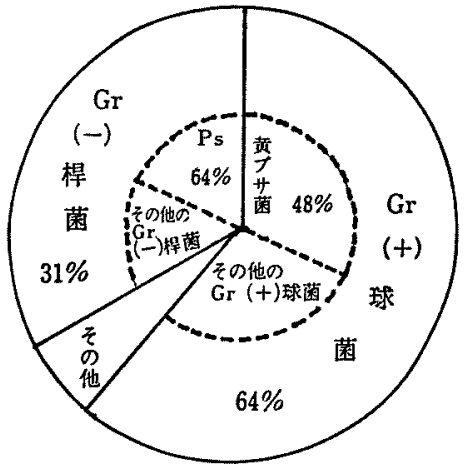

第 4 表 急性中耳炎耳漏検出菌

\begin{tabular}{|c|c|c|}
\hline & 菌 & 株 数 \\
\hline 1 & 黄色ブドウ球菌 & 45 \\
\hline 2 & 表皮ブドウ球菌 & 25 \\
\hline 3 & 肺 炎 双 球 菌 & 22 \\
\hline 4 & 膿菌 & 10 \\
\hline 5 & $シ ゙ フ$ テ & 9 \\
\hline 6 & 溶血性レンサ球菌 & 6 \\
\hline
\end{tabular}

第 5 表 各薬㓮デイスクに(州)を示した株の百分比， 年次別推移

(A) Staph. aureus $(0)$

\begin{tabular}{l|r|r|r|r|r|l}
\hline-19 & '63 & '64 & '65 & '66 & '67 & 平 均 \\
\hline \hline P C & 26 & 21 & 15 & 17 & 16 & $18 \%$ \\
S M & 61 & 47 & 55 & 55 & 58 & 54 \\
C P & 83 & 81 & 79 & 71 & 85 & 80 \\
T C & 79 & 72 & 73 & 63 & 75 & 75 \\
E M & 74 & 85 & 72 & 71 & 64 & 74 \\
Sulf & 9 & 7 & 3 & 10 & 20 & 9 \\
\hline
\end{tabular}

(B) Ps. aeruginosa (\%)

\begin{tabular}{c|c|c|r|r|r|r}
\hline 19 & '63 & '64 & '65 & '66 & '67 & 平 均 \\
\hline \hline S M & 8 & 0 & 12 & 20 & 14 & $10 \%$ \\
C P & 2 & 1 & 3 & 8 & 5 & 4 \\
T C & 8 & 7 & 10 & 19 & 21 & 12 \\
Sulf & & 1 & 0 & 8 & 8 & 5 \\
C L & & & 86 & 81 & 90 & 88 \\
\hline
\end{tabular}

